\title{
Challenges in using allylthiourea and chlorate as specific nitrification inhibitors
}

Tatari, Karolina; Gülay, Arda; Thamdrup, B.; Albrechtsen, Hans-Jørgen; Smets, Barth F.

Published in:

Chemosphere

Link to article, DOI:

10.1016/j.chemosphere.2017.05.005

Publication date:

2017

Document Version

Peer reviewed version

Link back to DTU Orbit

Citation $(A P A)$ :

Tatari, K., Gülay, A., Thamdrup, B., Albrechtsen, H-J., \& Smets, B. F. (2017). Challenges in using allylthiourea and chlorate as specific nitrification inhibitors. Chemosphere, 182, 301-305.

https://doi.org/10.1016/j.chemosphere.2017.05.005

\section{General rights}

Copyright and moral rights for the publications made accessible in the public portal are retained by the authors and/or other copyright owners and it is a condition of accessing publications that users recognise and abide by the legal requirements associated with these rights.

- Users may download and print one copy of any publication from the public portal for the purpose of private study or research.

- You may not further distribute the material or use it for any profit-making activity or commercial gain

- You may freely distribute the URL identifying the publication in the public portal 


\title{
Challenges in using allylthiourea and chlorate as specific nitrification inhibitors
}

\author{
K. Tatari ${ }^{\mathrm{a}}$, A. Gülay ${ }^{\mathrm{a}}$, B. Thamdrup ${ }^{\mathrm{b}}$, H.-J. Albrechtsen ${ }^{\mathrm{a}}$, B. F. Smets ${ }^{\mathrm{a}, *}$ \\ ${ }^{a}$ Department of Environmental Engineering, Technical University of Denmark, Miljøvej 113, \\ 2800 Kgs. Lynby, Denmark \\ ${ }^{b}$ Nordic Center for Earth Evolution, Department of Biology, University of Southern Denmark, \\ Campusvej 55, 5230 Odense, Denmark
}

\begin{abstract}
Allylthiourea (ATU) and chlorate $\left(\mathrm{ClO}_{3}^{-}\right)$are often used to selectively inhibit nitritation and nitratation. In this work we identified challenges with use of these compounds in inhibitory assays with filter material from a biological rapid sand filter for groundwater treatment. Inhibition was investigated in continuous-flow lab-scale columns, packed with filter material from a full-scale filter and supplied with $\mathrm{NH}_{4}^{+}$or $\mathrm{NO}_{2}^{-}$. ATU concentrations of $0.1-0.5 \mathrm{mM}$ interfered with the indophenol blue method for $\mathrm{NH}_{4}^{+}$quantification leading to underestimation of the measured $\mathrm{NH}_{4}^{+}$concentration. Interference was stronger at higher ATU levels and resulted in no $\mathrm{NH}_{4}^{+}$detection at $0.5 \mathrm{mM}$ ATU. $\mathrm{ClO}_{3}^{-}$at typical concentrations for inhibition assays (1-10 mM) inhibited nitratation by less than $6 \%$, while nitritation was instead inhibited by $91 \%$ when $\mathrm{NH}_{4}^{+}$was supplied. On the other hand, nitratation was inhibited by $67-71 \%$ at $10-20 \mathrm{mM} \mathrm{ClO}_{3}^{-}$when $\mathrm{NO}_{2}^{-}$was supplied, suggesting significant nitratation inhibition at higher $\mathrm{NO}_{2}^{-}$concentrations. No chlorite $\left(\mathrm{ClO}_{2}^{-}\right)$was detected in the effluent, and thus we could not confirm that nitritation inhibition was caused by $\mathrm{ClO}_{3}^{-}$reduction to $\mathrm{ClO}_{2}^{-}$. In conclusion, $\mathrm{ATU}$ and $\mathrm{ClO}_{3}^{-}$ should be used with caution in inhibition assays, because analytical interference
\end{abstract}


and poor selectivity for the targeted process may affect the experimental outcome and compromise result interpretation.

Keywords:

drinking water, ammonium, nitrite, ATU, chlorate, inhibition

\section{Introduction}

Aerobic nitrification is a two-step process consisting of the oxidation of ammonium to nitrite (nitritation) and of nitrite to nitrate (nitratation). Ammonium oxidizing bacteria ( $\mathrm{AOB}$ ) and ammonium oxidizing archaea (AOA) are responsible for nitritation (Martens-Habbena et al., 2009; Martens-Habbena and Stahl, 2011; Prosser, 1989; Prosser and Nicol, 2008), whereas nitrite oxidizing bacteria (NOB) oxidize nitrite to nitrate (Lees and Simpson, 1957). The two nitrification steps are linked and take place simultaneously as nitratation uses the product of nitritation, but can be uncoupled and investigated individually using compounds that inhibit one of the two steps. Inhibition is the result of blockage or inactivation of the normal catalytic cycle of the enzyme responsible for a specific function, i.e. nitritation or nitratation (McCarty, 1999).

Allylthiourea (ATU) is commonly used to inhibit nitritation, by targeting the ammonia monooxygenase action and chelating the copper in the active site, ultimately hindering its function (Bedard and Knowles, 1989). Nitritation inhibition has been used in micropollutant biodegradability studies (Batt et al., 2006; Falas et al., 2012; Shi et al., 2004; Zhou and Oleszkiewicz, 2010; Rattier et al., 2014) and in studies investigating nitritation kinetics (Munz et al., 2010) and activity (Dapena-Mora et al., 2007).

Chlorate $\left(\mathrm{ClO}_{3}^{-}\right)$has been used to inhibit nitrite oxidation and inhibition is 
presumably a result of chlorate reduction to chlorite $\left(\mathrm{ClO}_{2}^{-}\right)$(Hynes and Knowles, 1983). This reduction is catalyzed by nitrate reductase, which is actually the same enzyme that is responsible for nitrite oxidation, operating in the reverse direction (Hynes and Knowles, 1983). As a result, chlorate inhibition is assumed to be specific for nitritation. Chlorate inhibition has also been widely used when quantifying the ammonium oxidation potential of biomass (Belser and Mays, 1980; ISO, 2012).

Specific inhibition by ATU and chlorate has been used for decades in a variety of environmental systems, ranging from soils to activated sludge, marine sediments and pure cultures. Although similar behavior with other oligotrophic systems was expected, we experienced challenges with the use of these compounds in inhibition assays with filter material from biological rapid sand filters for groundwater treatment. The aim of this work was therefore to investigate, adress and report these challenges to avoid the potential occurrence of experimental artifacts in future work.

\section{Materials \& Methods}

\subsection{Investigated rapid sand filter and filter material sampling}

A rapid sand filter at Islevbro waterworks (Copenhagen, Denmark operated by Hofor A/S) was used for the experimental investigations. The filter had been operating for 30 years prior to the experiments without filter material replacement. Filter influent contained on average $0.13 \mathrm{mg} / \mathrm{L} \mathrm{NH}_{4}^{+}-\mathrm{N}$, which was completely nitrified to $\mathrm{NO}_{3}^{-}, 9.25 \mathrm{mg} / \mathrm{L} \mathrm{O}_{2}, 1.93 \mathrm{mg} / \mathrm{L} \mathrm{NVOC}$, and $0.1 \mathrm{mg} / \mathrm{L} \mathrm{Fe}^{+2}$ (Tatari et al., 2013). Filter material was collected from the top $5 \mathrm{~cm}$ using a sterilized $1 \mathrm{~L}$ stainless steel container attached to an extendable aluminum rod. Three random 
horizontal locations were sampled and the collected filter material was mixed to form a composite sample. After sampling, the sand was stored wet at $4{ }^{\circ} \mathrm{C}$ for less than 7 days before the inhibition assays.

\subsection{Inhibition assays}

The inhibitory effect of ATU and $\mathrm{ClO}_{3}^{-}$was investigated by monitoring the nitrification activity of the biomass on the collected filter material in a lab-scale assay. Due to the long operating time of the sampled full- scale filter, the filter material had an already established active nitrifying community, with AOB densities of 31 cells $/ \mathrm{m}^{3}$ filter material and a nitrification capacity above $223 \mathrm{~g} \mathrm{NH}_{4}^{+}-\mathrm{N} / \mathrm{m}^{3}$ filter material/d (Tatari et al., 2016). The experimental system employed small plexiglas columns ( $5 \mathrm{~cm}$ bed height, $2.6 \mathrm{~cm}$ inner diameter), packed with the collected filter material and operated continuously (Tatari et al., 2013). Effluent water from the waterworks was supplemented with 1-2 $\mathrm{mg} / \mathrm{L} \mathrm{NH}_{4}^{+}-\mathrm{N}$ as $\mathrm{NH}_{4} \mathrm{Cl}$ (SigmaAldrich, 254134) or $1 \mathrm{mg} / \mathrm{L} \mathrm{NO}_{2}^{-}-\mathrm{N}$ as $\mathrm{NaNO}_{2}$ (Sigma-Aldrich, S2252) and the inhibitory compounds at concentrations described later, and was fed at the inlet of the columns. Alkalinity in the influent water was high $\left(5.4 \mathrm{meq} / \mathrm{L}\right.$ as $\left.\mathrm{HCO}_{3}^{-}\right)$, so no additional alkalinity was added to the substrate water. The influent flowrate was constant at $39 \mathrm{~mL} / \mathrm{h}$ giving a hydraulic retention time (HRT) of $2.3 \mathrm{~h}$ in the system, as determined experimentally by salt $(\mathrm{NaCl})$ tracer tests. Column effluent was recirculated at a ratio of 50 to 1 to impose complete mixing in the bulk phase in the system (Tatari et al., 2013).

The columns were packed and started-up with only the $\mathrm{N}$-substrate in the influent, running therefore as controls for a day. On the second day of operation, the column effluents were sampled twice (with 3-4 $\mathrm{h}$ in between) and were analyzed for the $\mathrm{NH}_{4}^{+}, \mathrm{NO}_{2}^{-}$and $\mathrm{NO}_{3}^{-}$concentrations. After sampling of the con- 
trols, ATU (N-Allylthiourea, Merck chemicals, 808158) or $\mathrm{ClO}_{3}^{-}\left(\mathrm{KClO}_{3} \geq 99 \%\right.$, Sigma-Aldrich, 12634) were added in the influents and continously supplied with the N-substrates. ATU was only added in columns supplied with $\mathrm{NH}_{4}^{+} \cdot \mathrm{ClO}_{3}^{-}$ was added in columns supplied with $\mathrm{NO}_{2}^{-}$to verify nitratation inhibition, and in columns supplied with $\mathrm{NH}_{4}^{+}$to assess the selectivity of the nitratation inhibition. Concentrations of the two compounds and combinations with the N-substrates are reported in Table 1. The effluents were sampled twice (with 3-4 h in between), $18 \mathrm{~h}$ after the addition of the inhibiting compound (at least 8 HRT after onset of application) and were analyzed for $\mathrm{NH}_{4}^{+}, \mathrm{NO}_{2}^{-}$and $\mathrm{NO}_{3}^{-}$concentrations. Columns were then emptied and cleaned by high water flow $(390 \mathrm{~mL} / \mathrm{h})$ for $3-4 \mathrm{~h}$ before re-packing with new filter material for the next experiment, unless specified otherwise in Table 1.

Nitritation inhibition (\%) was calculated as the difference in $\mathrm{NH}_{4}^{+}$removal during control and test column performance. $\mathrm{NH}_{4}^{+}$removal (\%) was calculated by subtracting the effluent from the influent $\mathrm{NH}_{4}^{+}$concentration and normalizing for the influent $\mathrm{NH}_{4}^{+}$concentration. Similarly, nitratation inhibition (\%) was calculated as the difference of $\mathrm{NO}_{2}^{-}$removal during control and test column performance. $\mathrm{NO}_{2}^{-}$removal (\%) was calculated as the difference of effluent and produced $\mathrm{NO}_{2}^{-}$concentration, after correction for the $\mathrm{NO}_{2}^{-}$traces present in the influent water $\left(0.016 \mathrm{mg} / \mathrm{L} \mathrm{NO}_{2}^{-}-\mathrm{N}\right)$ and normalization for the produced $\mathrm{NO}_{2}^{-}$concentration. The $\mathrm{NO}_{2}^{-}$produced by nitritation was calculated as the difference of influent and effluent $\mathrm{NH}_{4}^{+}$concentration.

\subsection{Analytical methods}

$\mathrm{NH}_{4}^{+}$was quantified colorimetrically with the indophenol blue method (Merk, Spectroquant test kit, 1.14752) and absorbance was measured at $690 \mathrm{~nm}$ with a 
Table 1: Inhibitory effect of $\mathrm{ATU}$ and $\mathrm{ClO}_{3}^{-}$at different concentration levels on nitritation and nitratation

\begin{tabular}{|c|c|c|c|c|c|}
\hline & Inhibitor & & Influent & $\%$ & $\%$ \\
\hline \multirow[t]{2}{*}{ Inhibitor } & Concentration & Substrate & Substrate & Nitritation & Nitratation \\
\hline & $(\mathrm{mM})$ & & $(\mathrm{mg} \mathrm{N} / \mathrm{L})$ & Inhibition & Inhibition \\
\hline \multirow[t]{3}{*}{ ATU } & 0.10 & $\mathrm{NH}_{4}^{+}$ & 1 & 87 & 0.0 \\
\hline & $0.50^{\mathrm{i}}$ & & 1 & 87 & 0.0 \\
\hline & 0.50 & & 2 & 96 & 0.0 \\
\hline \multirow[t]{6}{*}{$\mathrm{ClO}_{3}^{-}$} & 0.01 & $\mathrm{NH}_{4}^{+}$ & 1 & 11 & 1.1 \\
\hline & 0.05 & & 1 & 15 & 0.0 \\
\hline & 0.10 & & 1 & 28 & 0.0 \\
\hline & 1.00 & & 1 & 83 & 1.9 \\
\hline & 5.00 & & 1 & 80 & 3.1 \\
\hline & 10.0 & & 1 & 85 & 5.9 \\
\hline \multirow[t]{3}{*}{$\mathrm{ClO}_{3}^{-}$} & 0.01 & $\mathrm{NO}_{2}^{-}$ & 1 & - & 5.4 \\
\hline & $10.0^{\mathrm{ii}}$ & & 1 & - & 67 \\
\hline & $20.0^{\mathrm{iii}}$ & & 1 & - & 71 \\
\hline
\end{tabular}

${ }^{\mathrm{i}}$ Same filter material as in the above experiment $(0.1 \mathrm{mM}$ ATU \& $1 \mathrm{mg} / \mathrm{L}$ $\mathrm{NH}_{4}^{+}$). ATU concentration was increased to $0.5 \mathrm{mM}$ at day 3 .

${ }^{\text {ii }}$ Same filter material as in the above experiment $\left(0.01 \mathrm{mM} \mathrm{ClO}_{3}^{-} \& 1 \mathrm{mg} / \mathrm{L}\right.$ $\mathrm{NO}_{2}^{-}$). $\mathrm{ClO}_{3}^{-}$concentration was increased to $10 \mathrm{mM}$ at day 3 .

iii Same filter material as in the above experiment $\left(10 \mathrm{mM} \mathrm{ClO}_{3}^{-} \& 1 \mathrm{mg} / \mathrm{L}\right.$ $\mathrm{NO}_{2}^{-}$). $\mathrm{ClO}_{3}^{-}$concentration was increased to $20 \mathrm{mM}$ at day 4 . 
spectrophotometer (Merck, DR 2800). Detection limit of the method was 0.05 $\mathrm{mg} \mathrm{NH}+4$. Measured $\mathrm{NH}_{4}^{+}$concentrations in the influents containing ATU were lower than the nominal spiked levels, so $\mathrm{NH}_{4}^{+}$was re-quantified by flow injection adapting the method from Hall and Aller (1992). In brief, the carrier stream was $10 \mathrm{mM} \mathrm{NaOH}$ (Sigma-Aldrich, 30620) with $0.2 \mathrm{M} \mathrm{Na-citrate} \mathrm{(Sigma-Aldrich,}$ 25116) and the receiving stream was $0.1 \mathrm{mM} \mathrm{HCl}$ (Sigma-Aldrich, 30721). Both streams were fed by a multi-channel pump (LabConco, Model 140250) at a rate of $6.2 \mathrm{~mL} / \mathrm{min} .100 \mu \mathrm{L}$ of sample were manually injected in the carrier stream through an injection valve. $\mathrm{NH}_{4}^{+}$in the sample was converted to gaseous $\mathrm{NH}_{3}$ due to the basic $\mathrm{pH}$ of the carrier stream. The carrier stream entered the gas exchange membrane (Teflon tape), through which $\mathrm{N} \mathrm{H}_{3}$ diffused to the receiving stream and was converted back to the ionic form $\left(\mathrm{NH}_{4}^{+}\right)$due to the acidic $\mathrm{pH}$. Conductivity of the receiving stream was measured by a conductivity meter (VWR Scientific, Model 1054) and was linearly correlated to the $\mathrm{N} \mathrm{H}_{4}$ content of the sample. Conductivity peaks were retrieved and processed with the Clarity software (Data Apex, Advanced Chromatography Data Station). Detection limit of the method was $0.07 \mathrm{mg} \mathrm{NH}_{4}^{+}-\mathrm{N}$.

$\mathrm{NO}_{3}^{-}, \mathrm{ClO}_{3}^{-}$and $\mathrm{ClO}_{2}^{-}$were quantified by Ion Chromatography (Dionex, ICS 1500) using a guard column (Dionex, AG 22) and an analytical column (Dionex, ION PAC AS22). The eluent solution contained $4.5 \mathrm{mM} \mathrm{Na}_{2} \mathrm{CO}_{3}$ (Sigma-Aldrich, 31432 ) and $1.4 \mathrm{mM} \mathrm{NaHCO}_{3}$ (Sigma-Aldrich, 71630), and detection was done by suppressed conductivity (Dionex Thermo Scientific, ASRS 300). Retention times were approximately $5.7 \mathrm{~min}$ for $\mathrm{NO}_{3}^{-}, 5 \mathrm{~min}$ for $\mathrm{ClO}_{3}^{-}$and $3.5 \mathrm{~min}$ for $\mathrm{ClO}_{2}^{-}$. Detection limits were $0.2 \mathrm{mg} \mathrm{NO}_{3}^{-}-\mathrm{N} / \mathrm{L}, 0.01 \mathrm{mM} \mathrm{ClO}_{3}^{-}$and $0.01 \mathrm{mM} \mathrm{ClO}_{2}^{-}$. 


\section{Results \& Discussion}

\subsection{ATU interference in $\mathrm{NH}_{4}^{+}$quantification by the indophenol blue method}

$\mathrm{NH}_{4}^{+}$quantification by the indophenol blue method resulted in lower $\mathrm{NH}_{4}^{+}$values compared to the concentrations measured by flow injection in all samples where ATU was present (Figure 1). $\mathrm{NH}_{4}^{+}$concentration measured by flow injection in the influent samples matched the nominal spiked concentrations and fitted the N-balance within the standard error of the analytical methods (data not shown).

To exclude a potential matrix effect, 7 standard solutions were prepared by spiking the effluent water from Islevbro waterworks with $\mathrm{NH}_{4}^{+}-\mathrm{N}$ at $0.05-1 \mathrm{mg} / \mathrm{L}$. The standard solutions were analyzed colorimetrically and $\mathrm{NH}_{4}^{+}$was retrieved in all standards within the standard deviation of the method $(0.023 \mathrm{mg} \mathrm{NH}+$-N/L). A second series of 4 standard solutions in the same water matrix contained 1 $\mathrm{mg} / \mathrm{L} \mathrm{NH}_{4}^{+}-\mathrm{N}$ and $0.05-0.5 \mathrm{mM}$ ATU, and was also quantified colorimetrically. Measured $\mathrm{NH}_{4}^{+}-\mathrm{N}$ concentrations were between 0 and $0.80 \mathrm{mg} / \mathrm{L}$, confirming the underestimation of $\mathrm{NH}_{4}^{+}$concentration by the indophenol blue method in the presence of ATU.

Interference by ATU in the flow injection method was excluded by analyzing a series of 6 standard solutions $\left(0.07-1.12 \mathrm{mg} / \mathrm{L} \mathrm{NH}_{4}^{+}-\mathrm{N}\right)$ without or with $0.5 \mathrm{mM}$ ATU, where all measured concentrations matched the nominal standard concentrations.

$\mathrm{NH}_{4}^{+}$analysis by the indophenol blue method did not detect any $\mathrm{NH}_{4}^{+}$in the influents spiked with $0.5 \mathrm{mM}$ ATU, although their nominal $\mathrm{NH}_{4}^{+}$concentration was 1-2 mg/L NH$+4-N$ (Figure 1). Interference of ATU with the colorimetric method was stronger at higher ATU concentrations. However, the $\mathrm{NH}_{4}^{+}$concentration from colorimetric determination was not correlated with the actual $\mathrm{NH}_{4}^{+}$concentration 


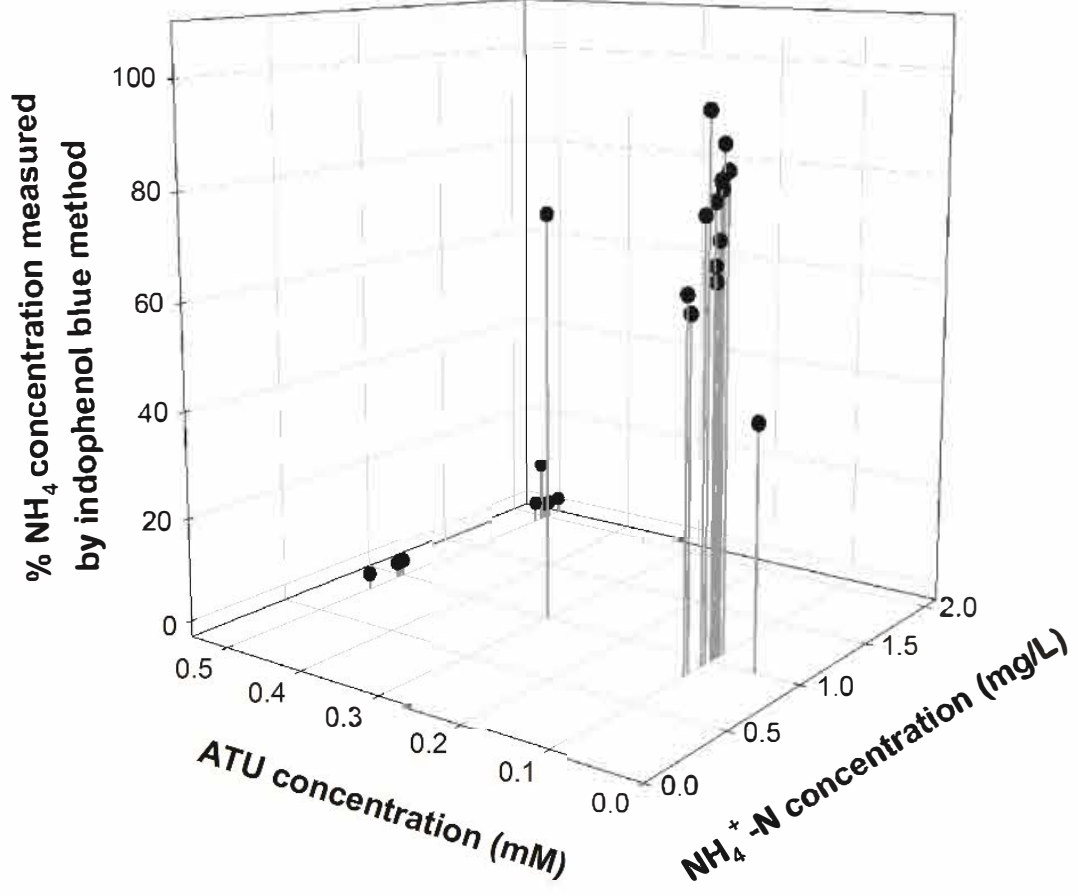

Figure caption

Figure 1: $\mathrm{NH}_{4}^{+}$concentration underestimation by the indophenol blue method when ATU was present in the samples 
for a given ATU level, so no correction factor could be calculated.

Although the indophenol blue method has been used in several works to quantify $\mathrm{NH}_{4}^{+}$in ATU inhibited samples (Law et al., 1992; Lehtovirta-Morley et al., 2013; Minzoni et al., 1988), this is the first study to identify and report the analytical interference of ATU with this method. These previous studies however, used ATU concentrations between 0.009 and $0.08 \mathrm{mM}$, which are lower than the range used in our study. Only Montuelle et al. (2003) using $1.7 \mathrm{mM}$ ATU suggested a potential interference in the $\mathrm{NH}_{4}^{+}$quantification, although they did not not investigate nor specifically attribute the interference to the presence of ATU. ATU concentrations up to $0.08 \mathrm{mM}$ are typically used to inhibit AOB activity, while higher concentrations up to $0.86 \mathrm{mM}$ are relevant for archaeal (AOA) activity inhibition (Santoro and Casciotti, 2011; Hatzenpichler et al., 2008; Taylor et al., 2010). Therefore, when ATU is used to inhibit AOA activity at concentrations higher than $0.08 \mathrm{M}$ the use of the indophenol blue method for $\mathrm{NH}_{4}^{+}$quantification should be discouraged. Erroneous conclusions can arise if only effluent $\mathrm{NH}_{4}^{+}$ concentrations are measured as they would be underestimated due to interference, resulting in overestimation of the ATU inhibitory effect.

\subsection{Selectivity of $\mathrm{ClO}_{3}^{-}$inhibition for nitratation}

The efficiency and selectivity of $\mathrm{ClO}_{3}^{-}$in inhibiting nitratation was evaluated by experiments with $\mathrm{NH}_{4}^{+}$or $\mathrm{NO}_{2}^{-}$as the supplied substrate. During the initial operation as controls, $\mathrm{NH}_{4}^{+}$removal in the columns supplied with $\mathrm{NH}_{4}^{+}$was higher than $98 \%$, and nitratation was complete since the effluent $\mathrm{NO}_{2}^{-}-\mathrm{N}$ concentration was below $0.016 \mathrm{mg} / \mathrm{L} . \mathrm{NO}_{2}^{-}$removal during the control operation of the columns supplied with $\mathrm{NO}_{2}^{-}$ranged between 88 and $97 \%$.

Inhibition observed due to $\mathrm{ClO}_{3}^{-}$addition is illustrated in Table 1 for the 9 
combinations of $\mathrm{N}$-substrates and $\mathrm{ClO}_{3}^{-}$concentrations. $\mathrm{ClO}_{3}^{-}$at 1-10 mM inhibited nitritation (80-85\%), but not nitratation $(<6 \%)$ in the columns supplied with $\mathrm{NH}_{4}^{+}$(Table 1). On the other hand, nitratation was inhibited (67-71\%) at 10-20 $\mathrm{mM} \mathrm{ClO}_{3}^{-}$when $\mathrm{NO}_{2}^{-}$was the sole influent substrate (Table 1). This differential $\mathrm{ClO}_{3}^{-}$effect on nitratation can be possibly related to the different $\mathrm{NO}_{2}^{-}$concentration in the columns. At $10 \mathrm{mM} \mathrm{ClO}_{3}^{-}$, the effluent $\mathrm{NO}_{2}^{-}-\mathrm{N}$ concentration was 0.82 $\mathrm{mg} / \mathrm{L}$ in the column supplied with $\mathrm{NO}_{2}^{-}$and $0.02 \mathrm{mg} / \mathrm{L}$ in the column supplied with $\mathrm{NH}_{4}^{+}$. These effluent concentrations were equal to the $\mathrm{NO}_{2}^{-}$concentrations in the columns because of complete mixing in the system. Hence, this indicates that nitratation inhibition was higher at high vs. low $\mathrm{NO}_{2}^{-}$concentrations. Our results are in contrast with those of Belser and Mays (1980), who observed a stronger inhibitory effect at low $\mathrm{NO}_{2}^{-}$concentrations suggesting a competitive inhibition mechanism. Our results do not support such a mechanism, but indicate that different $\mathrm{NOB}$ communities may respond differently to $\mathrm{ClO}_{3}^{-}$.

Nitritation inhibition by $\mathrm{ClO}_{3}^{-}$has been observed previously and has been attributed to reduction of $\mathrm{ClO}_{3}^{-}$to $\mathrm{ClO}_{2}^{-}$by $\mathrm{NOB}$ (Hynes and Knowles, 1983). We did not detect $\mathrm{ClO}_{2}^{-}$in the column effluents ( $\mathrm{LOD} 0.02 \mathrm{mM}$ ), while the $\mathrm{ClO}_{3}^{-}$added to the influents was retrieved in the effluents (data not shown). We therefore could not confirm the hypothesized reduction of $\mathrm{C} 1 Q$ to $\mathrm{C} 1 \mathrm{Q}$ or the reduction to $\mathrm{Cl}^{-}$as suggested by Xu et al. (2011). This, however, does not exclude the possibility that $\mathrm{ClO}_{3}^{-}$was temporarily reduced and oxidized in a cyclic pattern, producing intermediates that inhibited nitritation. According to Hynes and Knowles (1983), AOB are presumably much more sensitive than $\mathrm{NOB}$ to $\mathrm{ClO}_{2}^{-}$, meaning that even low concentrations may inhibit nitritation. These observations ultimately suggest that selectivity of $\mathrm{ClO}_{3}^{-}$inhibition towards nitratation may be compromised by specific 
experimental factors, such as the $\mathrm{NO}_{2}^{-}$concentration and the type of active NOB. Therefore, the $\mathrm{ClO}_{3}^{-}$inhibition method to estimate nitrification potential should be tested before use to exclude an eventual significant nitritation inhibition during the assay that may lead to experimental artifacts .

\section{Acknowledgements}

This work was supported by the Danish Council for Strategic Research via project DW-Biofilters. The authors acknowledge the Urban Water Technology Research School and the waterworks involved in this study.

\section{References}

Batt, A.L., Kim, S., Aga, D.S., 2006. Enhanced biodegradation of iopromide and trimethoprim in nitrifying activated sludge. Environmental Science \& Technology $40,7367-7373$.

Bedard, C., Knowles, R., 1989. Physiology, biochemistry, and specific inhibitors of $\mathrm{CH}_{4}, \mathrm{NH}_{4}^{+}$, and $\mathrm{CO}$ oxidation by methanotrophs and nitrifiers. Microbiological Reviews 53, 68-84.

Belser, L.W., Mays, E.L., 1980. Specific inhibition of nitrite oxidation by chlorate and its use in assessing nitrification in soils and sediments. Applied and Environmental Microbiology 39, 505-510.

Dapena-Mora, A., Fernandez, I., Campos, J.L., Mosquera-Corral, A., Mendez, R., Jetten, M.S.M., 2007. Evaluation of activity and inhibition effects on anammox process by batch tests based on the nitrogen gas production. Enzyme and Microbial Technology 40, 859-865. 
Falas, P., Andersen, H.R., Ledin, A., Jansen, J.L., 2012. Impact of solid retention time and nitrification capacity on the ability of activated sludge to remove pharmaceuticals. Environmental Technology 33, 865-872.

Hall, P.O., Aller, R.C., 1992. Rapid, small-volume, flow injection analysis for sigma- $\mathrm{CO}_{2}$ and $\mathrm{NH}_{4}^{+}$in marine and freshwaters. Limnology and Oceanography 37, 1113-1119.

Hatzenpichler, R., Lebedeva, E.V., Spieck, E., Stoecker, K., Richter, A., Daims, H., Wagner, M., 2008. A moderately thermophilic ammonia-oxidizing crenarchaeote from a hot spring. Proceedings of the National Academy of Sciences of the United States of America 105, 2134-2139.

Hynes, R.K., Knowles, R., 1983. Inhibition of chemoautotrophic nitrification by sodium chlorate and sodium chlorite: a reexamination. Applied and Environmental Microbiology 45, 1178-1182.

ISO, 2012. Soil quality - Determination of potential nitrification and inhibition of nitrification - Rapid test by ammonium oxidation. ISO 15685. International Organization for Standardization. Geneva, Switzerland.

Law, C.S., Rees, A.P., Owens, N.J.P., 1992. Nitrous oxide: estuarine sources and atmospheric flux. Estuarine Coastal and Shelf Science 35, 301-314.

Lees, H., Simpson, J.R., 1957. The biochemstry of the nitrifying organisms. 5. Nitrite oxidation by nitrobacter. Biochemical Journal 65, 297-305.

Lehtovirta-Morley, L.E., Verhamme, D.T., Nicol, G.W., Prosser, J.I., 2013. Effect of nitrification inhibitors on the growth and activity of nitrosotalea devanaterra in culture and soil. Soil Biology \& Biochemistry 62, 129-133. 
Martens-Habbena, W., Berube, P.M., Urakawa, H., de la Torre, J.R., Stahl, D.A., 2009. Ammonia oxidation kinetics determine niche separation of nitrifying archaea and bacteria. Nature 461, 976-979.

Martens-Habbena, W., Stahl, D.A., 2011. Nitrogen metabolism and kinetics of ammonia-oxidizing archaea. Methods in Enzymology 496, 465-487.

McCarty, G.W., 1999. Modes of action of nitrification inhibitors. Biology and Fertility of Soils 29, 1-9.

Minzoni, F., Bonetto, C., Golterman, H.L., 1988. The nitrogen cycle in shallow water sediment systems of rice fields. Part 1: the denitrification process. Hydrobiologia 159, 189-202.

Montuelle, B., Balandras, B., Volat, B., Feray, C., 2003. Effect of wastewater treatment plant discharges on the functional nitrifying communities in river sediments. Aquatic Ecosystem Health \& Management 6, 381-390.

Munz, G., Mori, G., Vannini, C., Lubello, C., 2010. Kinetic parameters and inhibition response of ammonia- and nitrite-oxidizing bacteria in membrane bioreactors and conventional activated sludge processes. Environmental Technology $31,1557-1564$.

Prosser, J.I., 1989. Autotrophic nitrification in bacteria. Advances in Microbial Physiology 30, 125-181.

Prosser, J.I., Nicol, G.W., 2008. Relative contributions of archaea and bacteria to aerobic ammonia oxidation in the environment. Environmental Microbiology 10, 2931-2941. 
Rattier, M., Reungoat, J.and Keller, J., Gernjak, W., 2014. Removal of micropollutants during tertiary wastewater treatment by biofiltration: Role of nitrifiers and removal mechanisms. Water Research 54, 89-99.

Santoro, A.E., Casciotti, K.L., 2011. Enrichment and characterization of ammonia-oxidizing archaea from the open ocean: phylogeny, physiology and stable isotope fractionation. Isme Journal 5, 1796-1808.

Shi, J., Fujisawa, S., Nakai, S., Hosomi, M., 2004. Biodegradation of natural and synthetic estrogens by nitrifying activated sludge and ammonia-oxidizing bacterium nitrosomonas europaea. Water Research 38, 2323-2330.

Tatari, K., Smets, B.F., Albrechtsen, H.J., 2013. A novel bench-scale column assay to investigate site-specific nitrification biokinetics in biological rapid sand filters. Water Research 47, 6380-6387.

Tatari, K., Smets, B.F., Albrechtsen, H.J., 2016. Depth investigation of rapid sand filters for drinking water production reveals strong stratification in nitrification biokinetic behavior. Water Research 101, 402-410.

Taylor, A.E., Zeglin, .H., Dooley, S., Myrold, D.D., Bottomley, P.J., 2010. Evidence for different contributions of archaea and bacteria to the ammoniaoxidizing potential of diverse oregon soils. Applied and Environmental Microbiology 76, 7691-7698.

Xu, G.J., Xu, X.C., Yang, F.L., Liu, S.T., 2011. Selective inhibition of nitrite oxidation by chlorate dosing in aerobic granules. Journal of Hazardous Materials $185,249-254$. 
311 Zhou, X.K., Oleszkiewicz, J.A., 2010. Biodegradation of oestrogens in nitrifying activated sludge. Environmental Technology 31, 1263-1269. 


\section{Addendum}

Since the original submission of this article, we have discovered - using 16S rRNA targeted amplicon sequencing and qPCR - that the microbial community on the sand material from the examined rapid sand filters is highly enriched in members of the Nitrospira over the Nitrosomonas genus (ca 100/1, (Gülay et al., 2016; Tatari et al., 2016)) We subsequently discovered - via metagenomics - that the Nitrospira population was dominated by types with the genetic capacity for complete ammonium oxidation (comammox) (Palomo et al., 2016). Our recent work - using stable isotope probing - reveals that comammox Nitrospira drive ammonium oxidation in the RSF samples under the examined conditions (Gülay et al., unpublished). Hence, our observations on the behavior of $\mathrm{ClO}_{3}{ }^{-}$as a strong inhibitor of nitritation can be explained: even though $\mathrm{ClO}_{3}{ }^{-}$is only converted to the toxic $\mathrm{ClO}_{2}{ }^{-}$in cells that have an active nitriteoxidoreductase enzyme (NXR, i.e. perform nitratation), the majority of these cells are likely comammox Nitrospira, and the toxic $\mathrm{ClO}_{2}{ }^{-}$ would then not only inhibit most cells in their nitrite oxidation capacity (nitratation) but also in their ammonium oxidation capacity (nitritation). The observed 'lack of nitratation inhibition' under ammoniumfed conditions can also be explained: as nitritation inhibition is not $100 \%$ complete, there are some cells that are not affected by $\mathrm{ClO}_{3}{ }^{-}$; those cells' nitration capacity would then neither be affected, limited-to-no $\mathrm{NO}_{2}{ }^{-}$ accumulation would be observed, and absence of nitritation inhibition would be inferred. Yet, we note that $\mathrm{ClO}_{3}{ }^{-}$causes strong nitratation inhibition when $\mathrm{NO}_{2}{ }^{-}$is provided as sole substrate: this is consistent with the normal mode of action of $\mathrm{ClO}_{3}{ }^{-}$, either by inhibiting comammox Nitrospira or other NOBs that oxidize extracellular $\mathrm{NO}_{2}{ }^{-}$. Clearly, our further observations on the abundance of comammox Nitrospira strengthen and refine the conclusion: the selectivity of $\mathrm{ClO}_{3}{ }^{-}$as inhibitor of nitratation may be compromised by the type of NOB and is abolished when comammox Nitrospira dominate ammonium oxidation in the system. These observations, furthermore, suggests that the response to $\mathrm{ClO}_{3}$ - may serve as an indicator of the contribution of comammox to nitrification.

Reference to be Added to the References:

Gülay A., Musovic S., Albrechtsen H.-J., Al-Soud W.A., Sørensen S.J. and Smets B.F., Ecological patterns, diversity and core taxa of microbial communities in groundwater-fed rapid gravity filters, ISME J. 10, 2016, 2209-2222

Palomo A., Fowler J. S., Gülay A., Rasmussen S., Sicheritz-Pontén T., and Smets B.F., Metagenomic analysis of rapid gravity sand filter microbial communities suggests novel physiology of Nitrospira spp, ISME J. 10, 2016, 2569-2581

Already in the list of references:

Tatari K., Smets B.F. and Albrechtsen H.J., Depth investigation of rapid sand filters for drinking water production reveals strong stratification in nitrification biokinetic behavior, Water Res. 101, 2016, 402-410 